\title{
Analysis of Industry Selection for Yunnan Enterprises to Invest in Bangladesh
}

\author{
Yong $\mathrm{Yu}$ \\ International Business School \\ Yunnan University of Finance and Economics \\ Kunming, China \\ yuyong01@vip.163.com \\ Yanfang Chen * \\ International Business School
}

\author{
Yunnan University of Finance and Economics \\ Kunming, China \\ coral_chanyf@163.com
}

\author{
Guangyu Li \\ International Business School \\ Yunnan University of Finance and Economics \\ Kunming, China \\ lgyu920@outlook.com
}

\begin{abstract}
The relationship between China and Bangladesh has reached a new level. The BCIM Economic Corridor and "the Belt and Road Initiative" will bring many opportunities for bilateral cooperation and exchange. They will bring opportunities for Yunnan enterprises to invest in Bangladesh as well. The paper analyses the basis of industry choice in Bangladesh and identifies complementary industries between China and Bangladesh. Finally, some advice about which industry Yunnan enterprises should choose to invest in Bangladesh is given to help them do better in investing in Bangladesh.
\end{abstract}

Keywords—Bangladesh; Investment; Industry selection

\section{INTRODUCTION}

Economic globalization and regional economic integration are the two major trends of the world economic development. The establishment and development of the SAARC conform to the trend of the era. So, China should actively develop relations of friendship with South Asia, promoting the development of bilateral trade. South Asian regional market has great potential. Especially the BCIM Economic Corridor and "the Belt and Road Initiative" provide more impetus to economic and trade cooperation between China and South Asia [1].

The situation of trade between China and South Asian countries and the establishment of Free Trade Area in South Asia has been research focus for the relevant scholars all over the world. But there is less fruitful research in Bangladesh. Yang Zhiping analyzed the investment environment in Bangladesh and the opportunities and risks to direct investment in the state [2-3]. Chen Lijun believes that Bangladesh is a country with a prominent geographical advantage in South Asia, and there is a long-term relation of friendship between China and Bangladesh [4]. Constantly expand the economic and trade cooperation with Bangladesh, which will become a strong point for China to open-door to the outside world in the new era.

In this paper, combined with the views of scholars, the complementary industries between Yunnan and Bangladesh

\footnotetext{
* Corresponding author
}

were identified. It provides a theoretical basis for Yunnan enterprises to invest in Bangladesh.

\section{REQUIREMENTS FOR YUNNAN ENTERPRISES INVEST IN BANGLADESH}

\section{A. Political and Investment Policies}

Bangladesh implements Representative system, the prime minister is the head of the cabinet, and the president is the head of state. There are two major political parties in the state: the people's Union and the Nationalist party. They are in turn alone or in combination with other small parties. Their struggle has never stopped since 1991, which leading to political instability, demonstrations and strikes. Once a party is in power, it will criticize, deny, and even override some of the policies and decisions made by the former government [5]. This makes the policy of Bangladesh unpredictable, and no continuity. In addition, the government's administrative procedures cumbersome, lack of transparency, serious bureaucratic habits, inefficient. These factors have led to the serious bribery of government officials, and many investment policies cannot be implemented. These have greatly increased the cost of investment in foreign enterprises.

Although the contradiction and struggle between the two parties continue, their attitude towards foreign investment is quite consistent. In order to stimulate rapid economic growth, attract foreign investment, no matter who is in power, it adopts the policy of supporting foreign direct investment to provide as much convenience and benefits as possible for foreign investment. Foreign investment in Bangladesh can enjoy a lot of convenience: First of all, the registration procedure for foreign investors to invest in Bangladesh is simple. Secondly, Bangladesh also provides tax relief for foreign investors and it implements national treatment to investors. Thirdly, there is no restriction on capital form and the proportion of equity. The country ensures that investment capital, profits and dividends can be remitted back to the home country and nationalization and expropriation of foreign capital will not be implemented without compensation. Finally, Private companies can invest in 
all areas except the weapons, arms and military installations and machinery, nuclear, coinage, cultivation in forest protection area and mechanized mining. In terms of trade, since becoming a member of WTO in 1995, Bangladesh has been working to cut tariffs sharply, but so far the level of tariff barriers in the country is still at a high level. In terms of foreign exchange, the country executes floating exchange rate system and the country's currency Taka can freely convertible in current account, such as import trade and travel. But capital projects such as investment and currency speculation are still under strict management. In terms of tax, the government formulates a series of industrial policy, import and export policies and export processing zone policies to achieve the effect of tax relief. So that investment and exports can be encouraged. Bangladesh encourages private investment and foreign investment. It is one of the countries that have the most liberal investment policies in the South Asian region.

Since 1975, Bangladesh has reached bilateral friendly diplomatic relations with China. The friendly relations between China and Bangladesh can provide a good political guarantee for trade and economic cooperation [6]. And both of parties have shown friendly attitude for Chinese investors. This helps Chinese investors to invest in Bangladesh. Bangladesh is actively promoting the construction of the Chinese economy industrial park. This park accounts for about 5,000 acres of land is currently being integrated investment zone in the vicinity of Chittagong, and the project will give Chinese investors more convenience and preferential policies. At the same time, the economy industrial park will feature clothing textiles, electronic appliances, automobile assembly, chemicals, and other industrial park, due to the Bangladesh government's policies.

\section{B. Economic and Trade Situation}

Since the mid of 1980 s, Bangladesh has committed to the implementation of a market driven free economic growth strategy. In the early 1990 s, this strategy was enhanced. What' more, the industrial policy was revised comprehensively in this years. All of these moves can promote trade and investment liberalization and can bring benefits to the construction of infrastructure and the development of private enterprises. And now, although the economy of Bangladesh has a high inflation rate, its overall trend is stable. In the newly released AEML, it ranked 28th in the world, which has improved than 2014 the 31 st. Bangladesh has therefore been considered as one of the countries that has the most potential of growth in emerging market countries. The growing economy has not only increased the country's wealth, but also created a growing group of middle-class. Bangladesh is a country with a population of 160 million, of which the class is sufficient to constitute a relatively large market. The growth of their demand for goods and services, coupled with their increasing purchasing power can created a huge market and activate the potential of this market. In addition, Bangladesh enjoys a free quota, Zero tariff and other preferential treatment in the European Union and other markets. These concessions can become China's channels to circumvent the relevant national trade barriers.

Bangladesh encourages private capital development and takes the policy and measures which can attract foreign direct investment. Fig.1 shows the status of external trade in Bangladesh in recent ten years. Bangladesh's imports and exports have been growing steadily, but the trade deficit has been growing as well. It is reported that Compared with the same period of last fiscal year, Bangladesh imports increased by $16.43 \%$, exports increased by $2.07 \%$ in the first 7 months of the 2014-2015 fiscal year. The trade deficit was $\$ 5$ billion 720 million, an increase of $\$ 2$ billion 930 million in the same period.

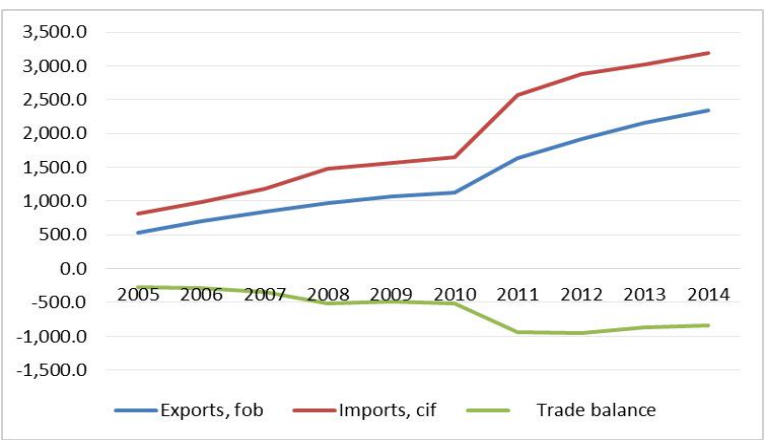

Fig. 1. 2005-2014 the external trade of Bangladesh (unit: billions of taka)

a. Sort from Asian Development Bank

Bangladesh foreign direct investment has been steadily increasing. As shown in Fig.2, from the perspective of the sources of investment, the main sources of investment in Bangladesh was China, India and Singapore. From 2005 to 2014, China's direct investment in Bangladesh amounted to more than the Chinese direct investment in Bangladesh up to a total of $\$ 49.162$ billion.

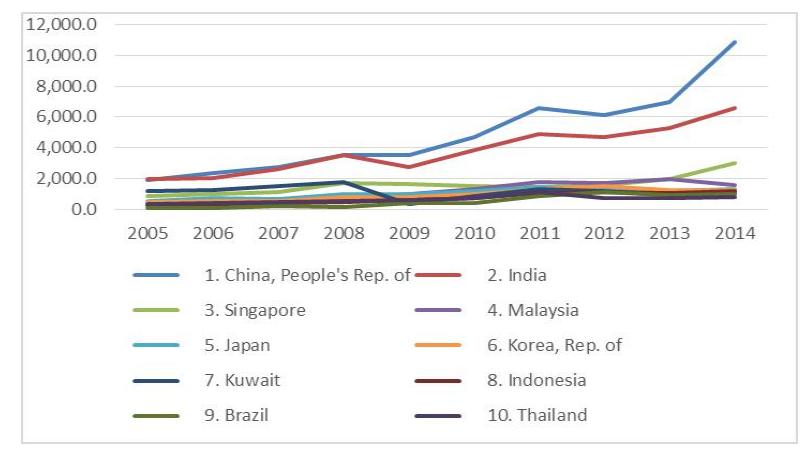

Fig. 2. $2005-2014$ The utilization of foreign investment situation in Bangladesh (unit: millions of dollars)

Yunnan and South Asia economic and trade cooperation has constantly changing. Over the past decade, gradual adjustment through Yunnan Import and Export support policies, removal of non-ferrous metals, phosphorus chemical products export support had increase exports of agricultural products, machinery and electrical products and light industrial products to support efforts to actively guide enterprises to optimize the export structure. Thought improving export value-added products, trade structure has undergone significant changes, and the initial plan of the import and export commodity structure adjustment and diversification had been achieved. BCIM Economic Corridor and China - South Asia Expo 
platform also contributed to the economic and trade cooperation between Yunnan and South Asia.

\section{Industries complementary}

Overall, the basic structure of opening Yunnan tourism, power, minerals, tobacco, agricultural plateau characteristics and a number of distinctive features, highlight the advantages of industry and industrial clusters had been formed. Initially formed to water, electricity based energy industry base; and gradually form a natural medicine-based pharmaceutical industry national key raw material base. Yunnan Province is striving to achieve net foreign trade exports each year to a new level, increase the "going out" pace, overseas project contracting turnover and foreign actual investment has intensified.

Industry and the growth rate distribution ratio of Bangladesh in recent 10 years as shown in Fig.3and4, the highest proportion is the service sector, which has been as high as 56.28 percent. The growth rate of the most stable, steady growth in the vicinity of $6 \%$. The share of industry take the second highest proportion of $27.61 \%$, the fastest pace of development of industry, the average growth rate of around $8 \%$. The minimum share is agriculture which has gradually decline, only $16.11 \%$ at currently. Its growth rate is lower and less stable hovering around 4\%. Although Bangladesh is an agricultural country, it still needs to import a lot of food for a rainy day facts every year. Therefore, Bangladesh has many opportunities of investment and cooperation in agriculture.

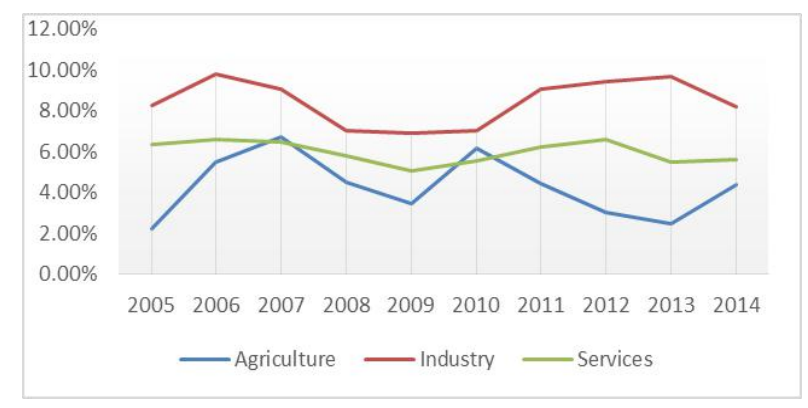

Fig. 3. 2005 --2014 The growth of agriculture, industry, service sector in Bangladesh

a. Sort from Asian Development Bank

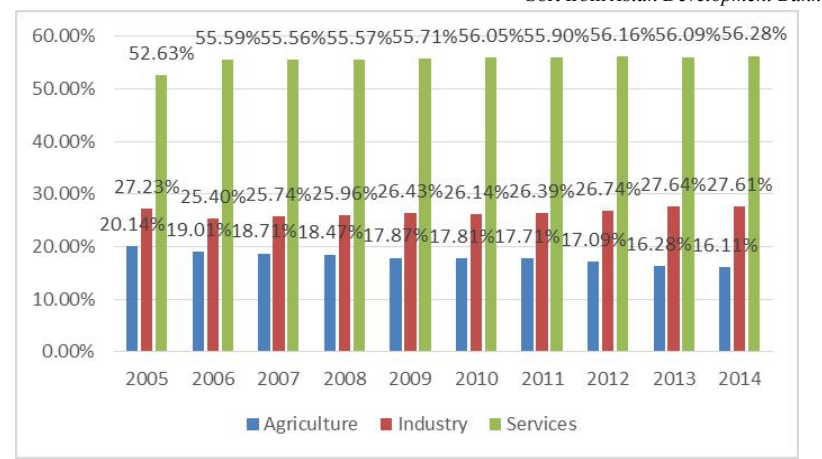

Fig. 4. 2005 --2014 Bangladesh GDP ratio sub categories
Although the current growth rate of industrial in Bangladesh as high as $8 \%$, but the proportion of GDP is only $27.61 \%$. So, it is a very important part for Bangladesh's current policy to strengthen industrial development to increase its share in the GDP. However, the country is still an agricultural country which has not yet entered the industrialized society. The agriculture's share of GDP has declined year by year, but, according to statistics, in 2014, there are 45 million 100 thousand people still engaged in agriculture in 60 million 700 thousand employed labor force in Bangladesh. That is to say, the number of farmers in Bangladesh accounts for $74.3 \%$ of the total labor force. The main industry of Bangladesh is raw material industry, including textile and garment industry, chemical fertilizer industry, cement industry, jute and jute products industry, leather and leather products industry, frozen food industry, tea and so on. The heavy industry is insignificant the manufacturing industry is underdeveloped, and the strategic industrial structure characterized by technology intensive is far from being formed. The country is eager to attract foreign direct investment in order to help them realize industrialization.

Infrastructure in Bangladesh is also very backward, such as frequent interruption of power supply, voltage instability. Not only the costs of installation of telephone fax and network are too high, but also the installation time is too long. The equipment frequently fails as well. The pressure of gas supply is insufficient and the gas is impure. And the water supply is always cut off. At the same time, there are many problems in the road and the port. The government of Bangladesh has fully realized that the backward and low efficiency of infrastructure is an important factor to restrict the economic development of Bangladesh, and the quality of infrastructure plays a vital role in attracting foreign investment. Bangladesh needs a lot of investment to improve its infrastructure. The Government of Bangladesh has been fully aware of this, so that infrastructure development has been identified as one of the areas of priority to the development of Bangladesh. Therefore, in the electric power, telecommunications and other infrastructure facilities in the areas of Bengal, where are lots of investment and cooperation opportunities.

In services sector, Bangladesh tourism industry is worth to be concerned. Bangladesh is very rich in tourism resources. It has a wide variety of tourist attractions, for example, it has the world's longest beach, a large number of forests, lakes and historical sites. But due to lack of planning and investment a large number of tourist attractions cannot be effectively developed in areas such as tourism development .So Bangladesh has been lagging behind its neighbors. It has only about 588000 foreign tourists each year. And its tourism income is about $\$ 101$ million. Compared with this, India attracts 6 million 680 thousand foreign tourists each year, and its tourism revenue is about $\$ 17$ billion each year. Due to the lack of awareness of the tourism resources in Bangladesh, besides the backward infrastructure and the lack of modern leisure tourism, the tourism industry of Bangladesh has not become a new growth point for the country's economic development. Despite all kinds of adverse conditions, Bangladesh has still rapid growth of tourism. Tourism now accounts for about 2.1 percent of GDP in Bangladesh, and in 2023 this number is expected to grow to around $6.4 \%$, which 
could take the first SAARC countries tourism growth rate ranks. This is also a new investment opportunities for foreign.

\section{Cheap Labor}

With the continuous development of China's economy and the rising living standards, the labor costs in China, especially in the coastal areas of China are increasing. What's more and the phenomenon of labor shortage is becoming more and more obvious. On the contrary, the population of Bangladesh is very large. There are 160 million people in Bangladesh, and it's one of the largest population density countries in the world. Its population density per square kilometer has reached 1060 people. Therefore, we can know that Bangladesh's labor resources are very abundant, which can make up for the shortage of labor in our country. In addition, abundant labor and low level of economic development, leading to a relative large wage competitiveness in Bangladesh. The salary of industrial workers is in general about 80 dollars a month, which is only $1 / 10$ of the monthly salary of Chinese workers. This is very suitable for enterprises in Yunnan province to put some labor-intensive industries in Bangladesh. Under the pattern of the regional integration of the world economy, the prices of commodity and raw material are substantially transparent and the basic public market is formed. Through the use of cheap labor to reduce its cost, enterprises can increase the international competitiveness of enterprises. Enterprises in Yunnan province can transfer some of the labor-intensive industries to Bangladesh. Which need to pay attention to is that Bangladesh technology structure of intensive industrial has not yet been formed, it suggests that the Bangladesh labor skill level is not high, and cannot be competent for some high technical requirements.

\section{INVESTMENT INDUSTRY SELECTION OF YUNNAN ENTERPRISES IN BANGLADESH}

A plenty of Chinese enterprises from Guangdong, Zhejiang, Shandong and other coastal cities have invested in Bangladesh. The field for these enterprises to invest in Bangladesh mainly involves textile industry, infrastructure, communications, energy and any other fields. Yunnan enterprises investing in Bangladesh remain largely blank, and have great development potential. According to analyze above, tourism, agriculture, electricity are more appropriate field for Yunnan enterprises to invest and copper with Bangladesh.

\section{A. Tourism}

Bangladesh is very rich in tourism resources, but the current overall tourism market in Bangladesh is relatively backward and primitive. Fortunately, the government of Bangladesh is very interested in the development of this field. And the country launched a new framework for tourism development in 2010, which focuses on the development of ecological tourism, rural tourism and cultural tourism experience etc. Besides it stresses the support for private investment in tourism development. The new law also allows foreign access to the relevant fields. Yunnan enterprises can use their own rich tourism and cultural resources and their development advantages, to carry out a number of cooperation and foreign investment, and help the Bangladeshi common develop. At the same time, the development of the tourism resources of Bangladesh helps Bangladesh open up new markets.

\section{B. Agriculture}

In agriculture, Yunnan is highly complementary to Bangladesh. For example, the flowers of Yunnan and the aquatic products of Bangladesh are complementary. In addition, Bangladesh is rich in resources, but the technology is backward Nevertheless, Yunnan has relatively high technology. Such as rice yield of Yunnan Agricultural University holds the world records, and the processing technology of agricultural byproduct in Yunnan is stronger than Bangladesh. Yunnan enterprises can invest in rice cultivation, as well as agricultural and the processing of agricultural by-product.

\section{Electric Power}

Bangladesh has a lot to do in infrastructure development. The infrastructure projects our country can invest in include power generation and transmission, telecommunications industry, port, airport, upgrade of railway and so on. Yunnan can also make a difference in these projects. Yunnan is abundant in relative resources, which has brought new opportunities for Yunnan's investment in Bangladesh's infrastructure. In addition, Yunnan's investment of electric power in Bangladesh is conducive to the construction of its infrastructure. At the same time, the improvement of infrastructure also provides more convenience, and reduces more cost for Yunnan enterprises to invest in Bangladesh.

\section{CONCLUSION}

This paper shows the prospects of the Yunnan enterprises which invest Bangladesh were feasible through the four aspects of policy concessions, economic development, industrial complementarity and cheap labor.

According to this, it gives the advice about choice of the industry to readers, in order to help enterprises in Yunnan can do better investment in Bangladesh. In addition, the BCIM Economic Corridor, the Belt and Road Initiative strategy, more and more offices set up in Bangladesh, all of these providing conveniences for Yunnan enterprises invest in Bangladesh.

Last but not least, it is required to pay attention to the coexistence of investment risks and returns in Bangladesh. So Yunnan enterprises need to be cautious when investing. Only by carefully analyzing the market, and full understanding the country's national conditions, policies, law, taxes and so on, can they make a reasonable decision for enterprises to invest.

\section{ACKNOWLEDGMENT}

I would like to express my gratitude to all those who helped me during the writing of this thesis. I gratefully acknowledge the help of my supervisor, Professor Yu Yong, who has offered me valuable suggestions in the academic studies. Without his patient instruction, insightful criticism and expert guidance, the completion of this thesis would not have been possible. 
I also owe a special debt of gratitude to all the professors in International Business School, from whose devoted teaching and enlightening lectures I have benefited a lot and academically prepared for the thesis.

\section{REFERENCES}

[1] "Report Bangladesh Investment and trade risk analysis," vol. 8, International Finance, 2011, pp. 65-67.
[2] Z.P. Yang, "Systematic analysis of investment environment in Bangladesh," vol. 6, International Economic Cooperation, 2006, pp. 5863.

[3] Z.P. Yang, "Direct Investment in Bangladesh: Opportunities and Risk Analysis," vol. 2, International Economic Cooperation, 2004, pp. 48-51.

[4] L.J. Chen, "Bangladesh: bridge between the Chinese and South Asian cooperation," Yunnan, vol. 4, Yunnan University of Finance and Economics, 2009, pp. 123-129.

[5] L.J. Chen, and S.L. Yang, "South Asia Report 2014-2015," Kunming: Yunnan University Press, 2015.

[6] J.J. Li, and Y.Z. Li, "Status and prospects of bilateral economic and trade relations between China and Bangladesh," vol. 4, South Asian Studies Quarterly, 2010, pp. 73-78+5-6. 